\title{
Metal Ion Measurement as a Diagnostic Tool to Identify Problems with Metal-on-Metal Hip Resurfacing
}

\author{
By K. De Smet, MD, R. De Haan, MD, A. Calistri, MD, P.A. Campbell, PhD, \\ E. Ebramzadeh, PhD, C. Pattyn, MD, and H.S. Gill, DPhil
}

Introduction

$\mathrm{M}$

etal-on-metal bearings for hip replacement are gaining popularity as an alternative to the most widely used bearing couple of metal on polyethylene'. The recent resurgence of hip resurfacing with the socalled third and fourth generations of hip resurfacing arthroplasty devices has played a substantial role in the wider use of metal-on-metal bearings ${ }^{2-4}$. Concerns about the wear of polyethylene and the role of polyethylene wear debris in the process of aseptic loosening have also increased the use of hardon-hard bearing couples.

However, wear still takes place with metal-on-metal bearings, and there is concern about the relatively high levels of metallic ions released into the body as a consequence. Cobalt-chromium alloy is the metal used for metal-on-metal implants and, while these elements are required for normal biological function, high concentrations of cobalt and chromium are toxic and are known to interfere with a number of biological processes ${ }^{5,6}$. The metal ion levels typically seen in patients with well-functioning metal-on-metal implants are not thought to be close to toxic levels ${ }^{7}$ and in many instances are not much higher than those in patients with metal-onpolyethylene implants ${ }^{8}$. However, there is a potential for much higher concentrations of metal wear products in the joint fluid in the vicinity of the bearing surfaces of poorly functioning metal-on-metal implants. It is these very high levels that are thought to be responsible for adverse reactions such as osteolysis $^{9}$ and the formation of soft-tissue masses ${ }^{10,11}$ and that give rise to metallosis (defined as gray discoloration of the hip joint $)^{12}$. It is not clear whether the levels of metal ions measured in blood serum are indicative of the metal ion concentrations in the joint fluid. Perhaps more importantly, the serum concentrations that are indicative of problems occurring with the bearing and high levels in the joint fluid and tissues have not been defined.
Detection of wear in metal-on-polyethylene couples is possible with use of radiographic methods to measure the penetration of the head into the polyethylene. This is not possible with metal-on-metal bearings. It is important to know if excessive wear is occurring, and this will play a key role in the management of patients who have a hip replacement. While it is accepted that metal ion measurements are important for monitoring metal-on-metal hip replacements ${ }^{13}$, a relationship between serum metal ion levels and wear has not been defined.

In the current study, we attempted to determine if measurement of serum ion levels could be used as a diagnostic tool by correlating blood and joint fluid metal-ion measurements with findings of metallosis and component wear at revision arthroplasty.

\section{Materials and Methods \\ Patients}

$\mathrm{B}^{\text {lood samples were collected from twenty-six consecutive }}$ $\mathrm{B}_{\text {patients with a metal-on-metal hip replacement, which }}$ was unilateral in nineteen and bilateral in seven, who were scheduled for a revision arthroplasty. The patients with a bilateral replacement were scheduled for revision on only one side. The blood was collected from most patients on the day of the revision, with the timing of the collection ranging from zero to seven days prior to the revision. All revisions were performed by one surgeon (K.D.S.). Hip joint fluid was collected and the presence or absence of metallosis was recorded during the revision procedure. The removed components were retained to measure the amount of wear when possible.

The underlying diagnoses leading to the primary surgery were osteoarthritis ( $85 \%$ of the patients), dysplasia $(11 \%)$, and osteonecrosis $(4 \%)$. The mean age at the time of the revision was 52.8 years (range, eighteen to seventy-four years). There were seven men and nineteen women. The pri-

Disclosure: In support of their research for or preparation of this work, one or more of the authors received, in any one year, outside funding or grants in excess of $\$ 10,000$ from the Los Angeles Orthopaedic Hospital Foundation. Neither they nor a member of their immediate families received payments or other benefits or a commitment or agreement to provide such benefits from a commercial entity. No commercial entity paid or directed, or agreed to pay or direct, any benefits to any research fund, foundation, division, center, clinical practice, or other charitable or nonprofit organization with which the authors, or a member of their immediate families, are affiliated or associated. 
The Journal of Bone \& JOINT SURGERY · JBJS.ORG VOLUME $90-\mathrm{A} \cdot \mathrm{SUPPLEMENT} 4 \cdot 2008$
Metal Ion Measurement as a Diagnostic Tool to

Identify Problems with Metal-on-Metal Hip Resurfacing

TABLE I Serum and Joint Fluid Metal-Ion Concentrations for the Entire Study Cohort $(\mathbf{N}=26)$

\begin{tabular}{|lllll|}
\hline \multicolumn{1}{|c}{ Variable } & Median & Minimum & Maximum & Interquartile Range \\
\hline Serum chromium level $(\mu \mathrm{g} / \mathrm{L})$ & 13.2 & 0.4 & 93 & 27.7 \\
Serum cobalt level $(\mu \mathrm{g} / \mathrm{L})$ & 5.8 & 1 & 94 & 22.65 \\
Joint fluid chromium level $(\mu \mathrm{g} / \mathrm{L})$ & 252 & 19 & 29,080 & 2142 \\
Joint fluid cobalt level $(\mu \mathrm{g} / \mathrm{L})$ & 201 & 13 & 5120 & 1399.2 \\
Ratio of fluid to serum chromium level & 47.4 & 10.5 & 394.4 & 59.46 \\
Ratio of fluid to serum cobalt level & 36.5 & 8.3 & 699.1 & 42.7 \\
\hline
\end{tabular}

mary metal-on-metal devices used in the series included both hip resurfacing arthroplasty devices and total hip arthroplasty devices. There were sixteen Birmingham hip resurfacing devices (Smith and Nephew, Memphis, Tennessee), three Articular Surface Replacement (ASR) hip resurfacing devices (DePuy, Warsaw, Indiana), and one Durom hip resurfacing device (Zimmer, Warsaw, Indiana). Three patients had an M2a device (Biomet, Warsaw, Indiana) and one patient had a Metasul couple, with an ExpanSys cup and a Zweymüller stem (Mathys Orthopaedics, Bettlach, Switzerland); these total hip arthroplasty devices all had a $28-\mathrm{mm}$ head size. Two patients had a combination of a resurfacing cup and a large modular head: one had a Durom cup with a modular head on a VerSys stem (Zimmer), and the other had an ASR cup with a modular head on a Corail stem (DePuy). The femoral head diameters of the resurfacings and large modular head devices ranged from 38 to $58 \mathrm{~mm}$.

The average time of the implant in situ prior to the revision was 2.9 years (range, 0.5 to 8.4 years). The reasons for the revision were a malpositioned component(s) in eighteen patients (fourteen with a malpositioned cup only, one with a malpositioned head only, and three with malpositioning of both components), osteolysis in three, a loose femoral component in two, a loose cup in two, and a fractured total hip arthroplasty stem in one.

\section{Methods}

Blood samples were taken with use of an intravenous catheter (Insyte-W; Becton Dickinson, Franklin Lakes, New Jersey). After the catheter was introduced, the metal needle was withdrawn and the first $5 \mathrm{~mL}$ of blood was discarded to avoid possible metal contamination from the needle. A second $5 \mathrm{~mL}$ of blood was then collected with use of a vacuum tube (Venosafe VF-106SAHL; Terumo Europe, Leuven, Belgium).

Hip joint fluid was collected, with use of a disposable plastic 5-mL syringe (Becton Dickinson), after the joint was exposed.

Serum and joint fluid levels of cobalt and chromium were measured with use of an inductively-coupled plasma mass spectrometry (ICP-MS) technique (ELAN DRC II; PerkinElmer Life and Analytical Sciences, Waltham, Massachusetts). These measurements were performed by the Laboratory of Clinical Biology at Ghent University Hospital, Ghent, Belgium. This laboratory quotes its quantification limit as $0.5 \mu \mathrm{g} / \mathrm{L}$ with a reproducibility of $5 \%$.

Wear measurements were performed with use of a coordinate measuring machine (BRT 504; Mitutoyo America, Aurora, Illinois) to record the shape of the implant from 400 measurements with a resolution limit of $0.5 \mu \mathrm{m}$. The maximum depth of each wear scar, in micrometers, was used in the analyses as the measure of wear.

\section{Analyses}

The serum and hip fluid metal-ion levels were compared between the patients with a unilateral replacement and those with a bilateral replacement. The data were examined for distribution and were found to be non-normally distributed. The Mann-Whitney $U$ test was used to examine the differences in distribution between the patients with a unilateral replacement and those with a bilateral replacement.

The Mann-Whitney $U$ test was used to compare the serum and joint fluid metal-ion levels and femoral component wear between the patients in whom metallosis was found during revision and those in whom it was not.

The data on the patients with a unilateral replacement were used to analyze the relationships between the serum and joint fluid levels and the maximum depth of femoral wear, as it was thought that bilateral implantation would affect serum levels. The correlations between these values were examined by calculating the correlation coefficient. Robust regression analysis was applied to the data; the serum levels were considered to be the independent variable, and the joint fluid levels and wear measurements were considered to be the dependent variables. The standard method of least-squares regression is very sensitive to outliers in the data to be analyzed. In order to reduce the sensitivity of the regression analysis to outliers, a bisquare weight scheme was implemented. This scheme minimizes a weighted sum of squares, with the weight given to each data point depending on how far the point is from the fitted line. Points near the line are given full weight. Points farther from the line are given reduced weight. Points that are farther from the line than would be expected by random chance are given zero weight. The robust regression analysis was used to fit both linear and exponential curves to the serum and joint fluid metal-ion levels. The form of the linear equations was $y=m x+c$, whereas that for the exponential equations was $y=a e^{b x}$. The developed regression equations 
The Journal of Bone \& JOINT SURGERY · JBJS.ORG VOLUME $90-\mathrm{A} \cdot$ SUPPLEMENT $4 \cdot 2008$
Metal Ion Measurement as a Diagnostic Tool to

Identify Problems with Metal-on-Metal Hip Resurfacing

TABLE II Differences Between Patients without and with Metallosis Found at Revision

\begin{tabular}{|c|c|c|c|c|c|c|c|c|c|}
\hline \multirow[b]{2}{*}{ Variable } & \multicolumn{4}{|c|}{ Without Metallosis } & \multicolumn{5}{|c|}{ With Metallosis } \\
\hline & Median & Minimum & Maximum & $\begin{array}{l}\text { Interquartile } \\
\text { Range }\end{array}$ & Median & Minimum & Maximum & $\begin{array}{l}\text { Interquartile } \\
\text { Range }\end{array}$ & $P$ Value \\
\hline $\begin{array}{l}\text { Serum chromium } \\
\text { level }(\mu g / L)\end{array}$ & 3.35 & 0.4 & 21.5 & 13.58 & 33.9 & 5.3 & 93 & 40.4 & 0.001 \\
\hline $\begin{array}{l}\text { Serum cobalt } \\
\text { level }(\mu \mathrm{g} / \mathrm{L})\end{array}$ & 3.2 & 1 & 14 & 4.53 & 33.8 & 4.3 & 94 & 40.88 & $<0.001$ \\
\hline $\begin{array}{l}\text { Joint fluid chromium } \\
\text { level }(\mu \mathrm{g} / L)\end{array}$ & 179.5 & 19 & 661 & 240.23 & 5136.5 & 155 & 29,080 & $16,264.25$ & 0.001 \\
\hline $\begin{array}{l}\text { Joint fluid cobalt } \\
\text { level }(\mu g / L)\end{array}$ & 106.25 & 13 & 769 & 165.3 & 2185 & 110 & 5120 & 2270.75 & 0.001 \\
\hline Femoral wear $(\mu m)$ & 10 & 2 & 36 & 18.3 & 49.5 & 7 & 184 & 41.25 & 0.002 \\
\hline
\end{tabular}

were then applied to the serum data for the patients with a bilateral arthroplasty; the predicted values for the hip joint fluid levels were compared with the actual measured values. Linear regression equations relating serum levels to wear were used to predict wear values for the serum data for the patients with a bilateral arthroplasty, which were again compared with the actual measured values. Two types of linear fit were developed for the serum levels and wear data; the first was unconstrained, and the second was constrained to go through zero (i.e., $\mathrm{c}=0$ ).

Robust regression analysis was performed with use of the Curve Fitting Toolbox (version 1.1) within the MATLAB software environment (version 6.5; The MathWorks, Natick, Massachusetts).

\section{Results}

7 he joint fluid levels of metal ions were at least an order of 1 magnitude higher than those measured in the serum (Fig. 1). In the whole cohort, the median ratio of the joint fluid chromium level to the serum chromium level was 47.4 (range, 10.5 to 394.4 ) and the median ratio of the joint fluid cobalt level to the serum cobalt level was 36.5 (range, 8.3 to 699.1) (Table I).

The median serum and joint fluid levels of chromium in the patients with a bilateral arthroplasty $(17.7 \mu \mathrm{g} / \mathrm{L}$ [range, 1.1 to $82.2 \mu \mathrm{g} / \mathrm{L}$ ] and $333.0 \mu \mathrm{g} / \mathrm{L}$ [range, 32.2 to $6464.0 \mu \mathrm{g} / \mathrm{L}]$, respectively) were higher than those in the patients with a unilateral arthroplasty $(9.4 \mu \mathrm{g} / \mathrm{L}$ [range, 0.4 to $93.0 \mu \mathrm{g} / \mathrm{L}$ ] and $201.0 \mu \mathrm{g} / \mathrm{L}$ [range, 19.0 to $29,080.0 \mu \mathrm{g} /$
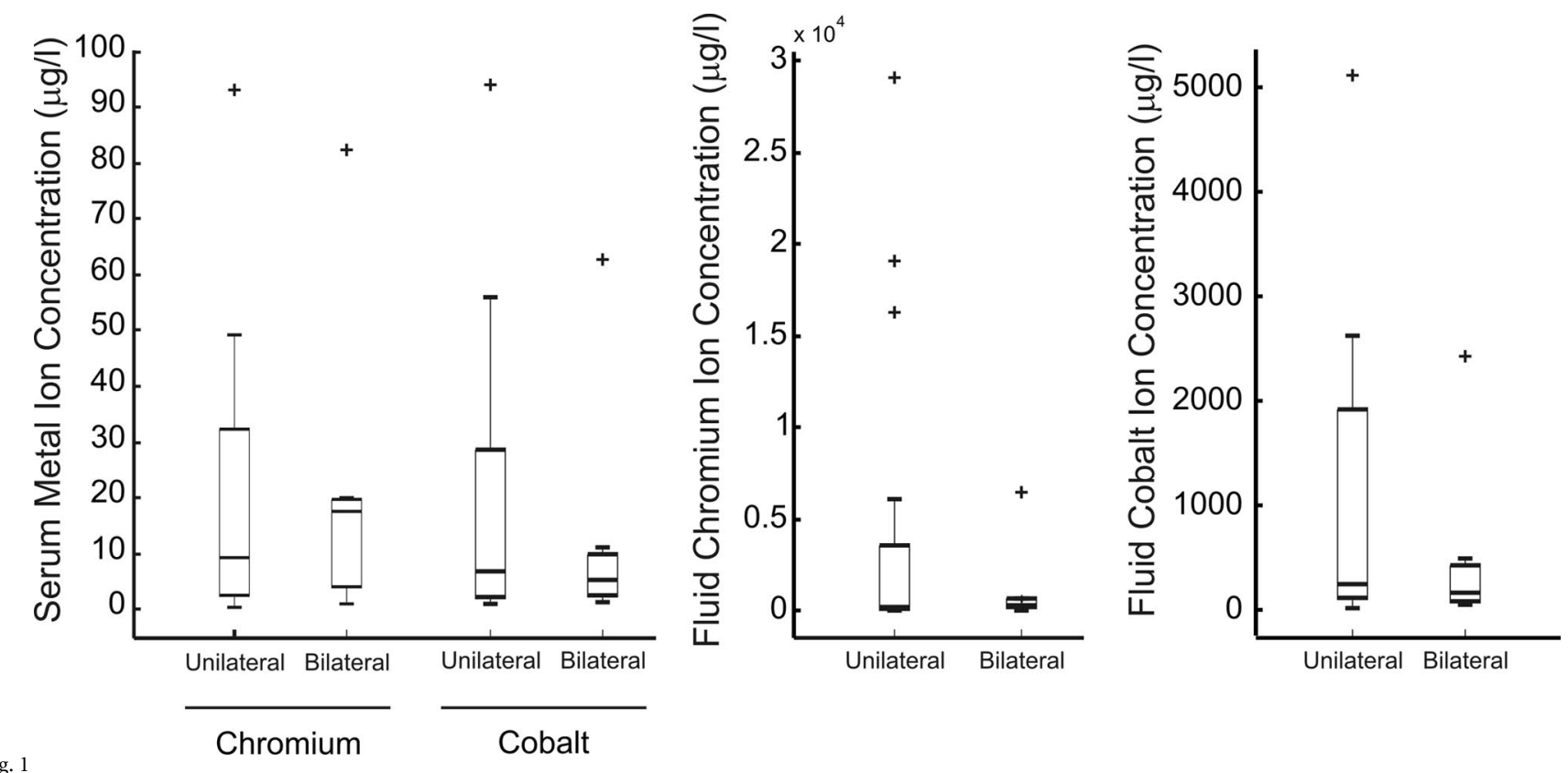

Differences in serum and joint fluid metal-ion concentrations for nineteen patients with a unilateral replacement and seven with a bilateral replacement. The interquartile range is shown as a box, containing a horizontal line indicating the median. The error bars indicate the extreme values within 1.5 times the interquartile range, and the plus symbols indicate outliers. 
The Journal of BOne \& JOINT SURGERY • JBJS.ORG VOLUME $90-\mathrm{A} \cdot$ SUPPLEMENT $4 \cdot 2008$
Metal Ion Measurement as a Diagnostic Tool to

Identify Problems With Metal-on-Metal Hip Resurfacing
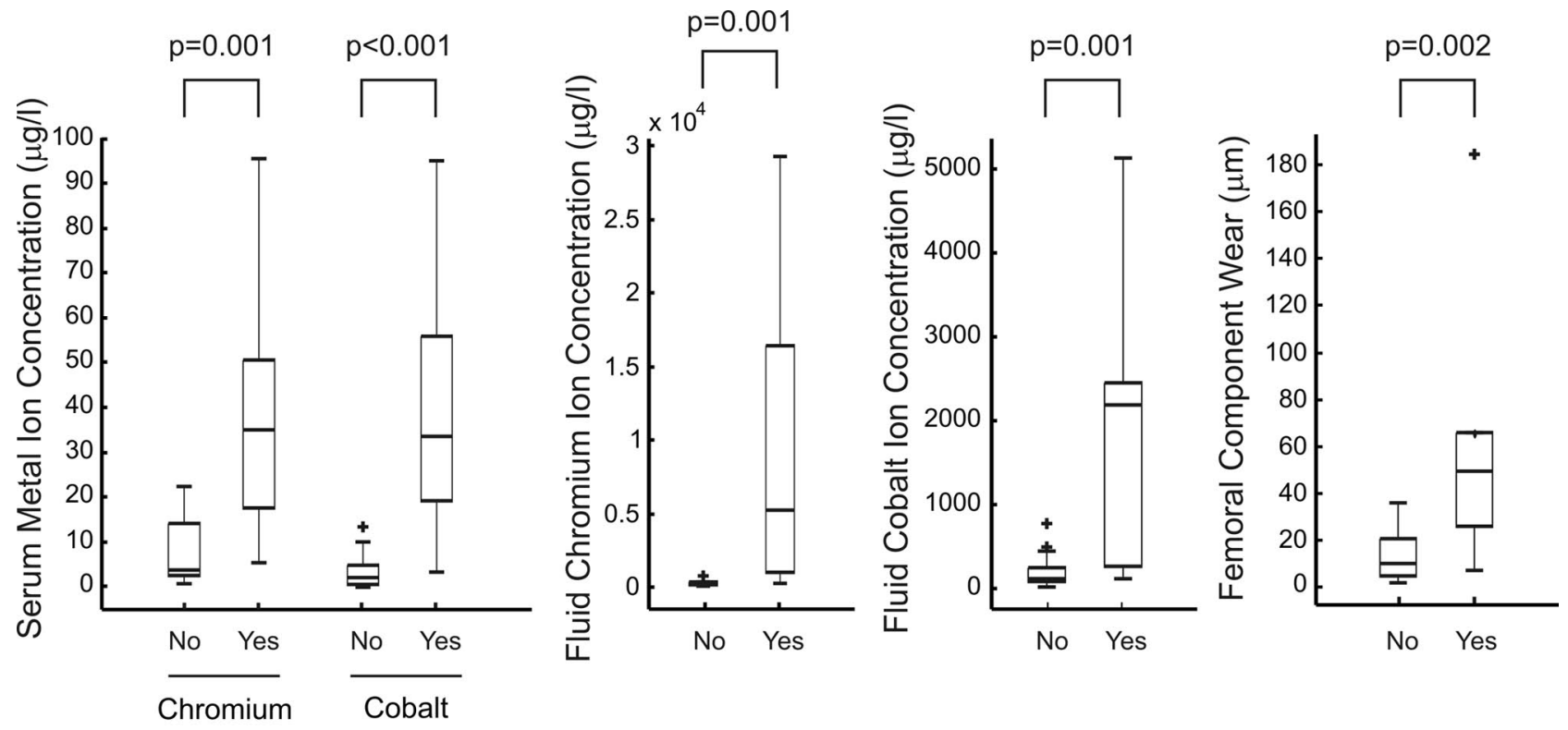

Fig. 2

Yes $=$ presence of metallosis found at revision

No $=$ metallosis not found at revision

Differences in serum and joint fluid metal-ion concentrations and femoral component wear between the patients with and those without metallosis found at revision. The interquartile range is shown as a box, containing a horizontal line indicating the median. The error bars indicate the extreme values within 1.5 times the interquartile range, and the plus symbols indicate outliers.

L]). Conversely, the median serum and joint fluid levels of cobalt in the patients with a bilateral arthroplasty $(5.3 \mu \mathrm{g} / \mathrm{L}$ [range, 1.4 to $62.7 \mu \mathrm{g} / \mathrm{L}$ ] and $153.0 \mu \mathrm{g} / \mathrm{L}$ [range, 38.4 to $2423.0 \mu \mathrm{g} / \mathrm{L}]$, respectively) were lower than the median levels in those with a unilateral arthroplasty $(6.9 \mu \mathrm{g} / \mathrm{L}$ [range, 1.0 to $94.0 \mu \mathrm{g} / \mathrm{L}$ ] and $235.0 \mu \mathrm{g} / \mathrm{L}$ [range, 13.0 to $5120.0 \mu \mathrm{g} /$ L]). With the number of subjects studied, these differences were not significant.

It was possible to perform wear measurements on nineteen femoral components, of which fifteen were from patients with a unilateral arthroplasty. Wear measurements were available for all ten patients in whom metallosis had been observed during the revision surgery and for nine of the patients without metallosis. The median serum chromium $(\mathrm{p}=0.001)$ and cobalt $(p<0.001)$ levels in the patients with metallosis were approximately ten times higher than those in the patients without metallosis (Fig. 2, Table II). The median joint fluid chromium level was twenty-eight times higher $(\mathrm{p}=0.001)$ and the median joint fluid cobalt level was twenty times higher $(\mathrm{p}=0.001)$ in the patients with metallosis. Femoral component wear in the patients with metallosis was approximately five times greater than that in the patients without metallosis $(\mathrm{p}=0.002)$.

There was a very high correlation between the serum and joint fluid metal concentrations (of both chromium and cobalt) (Fig. 3). For the patients with a unilateral arthroplasty, the correlation coefficients were 0.92 for chromium and 0.88 for cobalt, and these were highly significant $(\mathrm{p}<0.001$ for both chromium and cobalt). In the entire cohort of twenty-six patients, these correlations were also high (0.82 for chromium and 0.89 for cobalt) and significant ( $\mathrm{p}<0.001$ for both chromium and cobalt).

There were strong and significant correlations between femoral component wear and serum metal levels (Fig. 4), with correlation coefficients of 0.92 for chromium and 0.82 for cobalt ( $\mathrm{p}<0.001$ for both chromium and cobalt). There were also high correlations between femoral component wear and joint fluid metal levels, with correlation coefficients of 0.89 for chromium and 0.88 for cobalt $(\mathrm{p}<0.001$ for both chromium and cobalt).

Both linear and exponential curves showed reasonable fits to the serum and joint fluid metal-ion-level data (Fig. 3). The fit parameters ( $\mathrm{m}$ and $\mathrm{c}$ for the linear curves, and $\mathrm{a}$ and $\mathrm{b}$ for the exponential curves) were calculated with lower and upper 95\% confidence intervals, which are given in parentheses for the following values. For chromium, the linear fit gave $\mathrm{m}=$ $326.5(271,382)$ and $c=-1323(-3022,375.5)$, and the $R^{2}$ value was 0.899 . The exponential fit gave $\mathrm{a}=48.14$ (35.7, $60.58)$ and $b=0.124(-0.335,0.583)$, with an $R^{2}$ value of 0.959 . For cobalt, the linear fit gave $\mathrm{m}=39.5(33.56,45.44)$ and $c=-36.8(-221.6,148)$, and the $\mathrm{R}^{2}$ value was 0.954 . The exponential fit gave $\mathrm{a}=88.72(45.6,131.9)$ and $\mathrm{b}=0.058$ $(0.038,0.079)$, with an $\mathrm{R}^{2}$ value of 0.939 .

When the regression equations were applied to the serum levels in the patients with a bilateral arthroplasty, the median errors in predicted hip-joint-fluid levels of chromium were $3795.1 \mu \mathrm{g} / \mathrm{L}$ (range, 551.4 to $19,053.0 \mu \mathrm{g} / \mathrm{L}$ ) from the linear fit and $182.1 \mu \mathrm{g} / \mathrm{L}$ (range, $23.0 \mu \mathrm{g} / \mathrm{L}$ to $1.26 \times 10^{6} \mu \mathrm{g} / \mathrm{L}$ ) 
The Journal of Bone \& JOINT SURGERY • JBJS.org VOLUME $90-\mathrm{A} \cdot$ SUPPLEMENT $4 \cdot 2008$
Metal Ion Measurement as a Diagnostic Tool to

Identify Problems with Metal-on-Metal Hip Resurfacing

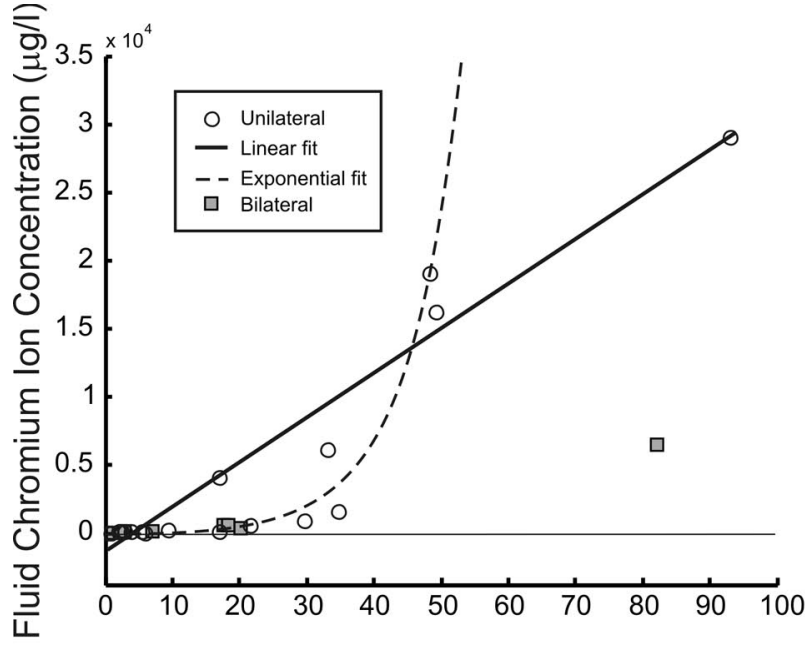

Serum Chromium lon Concentration $(\mu \mathrm{g} / \mathrm{l})$

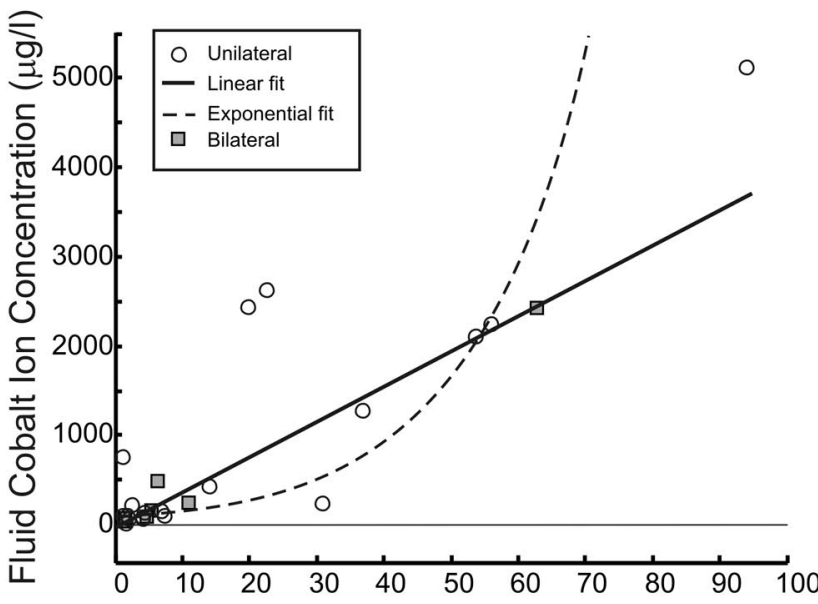

Serum Cobalt Ion Concentration $(\mu \mathrm{g} / \mathrm{l})$

Fig. 3

Linear and exponential fits to the relationships between joint fluid and serum metal-ion concentrations. Only data for the nineteen patients with a unilateral arthroplasty were used to develop the regression lines.

from the exponential fit. The median errors in predicted hipjoint-fluid levels of cobalt were $50.7 \mu \mathrm{g} / \mathrm{L}$ (range, 12.0 to 275.0 $\mu \mathrm{g} / \mathrm{L}$ ) from the linear fit and $59.0 \mu \mathrm{g} / \mathrm{L}$ (range, 18.5 to 1034.6 $\mu \mathrm{g} / \mathrm{L}$ ) from the exponential fit.

Both unconstrained and constrained linear regressions provided reasonable fits to the serum metal-ion and femoral component wear data (Fig. 4). For chromium levels and wear, the unconstrained linear fit gave $\mathrm{m}=1.04(0.67,1.42)$ and $\mathrm{c}=$ $7.05(-5.83,19.94)$ and the $\mathrm{R}^{2}$ value was 0.88 ; the constrained linear fit gave $\mathrm{m}=1.26(1.00,1.51)$, with an $\mathrm{R}^{2}$ value of 0.88 . For cobalt levels, the unconstrained linear fit gave $\mathrm{m}=0.98$ $(0.65,1.30)$ and $c=9.95(-1.25,21.15)$ and the $\mathrm{R}^{2}$ value was 0.90 ; the constrained fit gave $\mathrm{m}=1.24(0.99,1.50)$, with an $\mathrm{R}^{2}$ value of 0.88 .
When the regression equations were applied to the serum chromium levels in the patients with a bilateral arthroplasty, the median errors in predicted femoral component wear were $10.61 \mu \mathrm{m}$ (range, 1.21 to $26.63 \mu \mathrm{m}$ ) from the unconstrained linear fit and $8.44 \mu \mathrm{m}$ (range, 1.86 to $37.37 \mu \mathrm{m}$ ) from the constrained fit. The median errors in predicted femoral component wear from the serum cobalt levels in the patients with a bilateral arthroplasty were $7.79 \mu \mathrm{m}$ (range, 1.51 to $13.12 \mu \mathrm{m}$ ) from the unconstrained linear fit and $6.3 \mu \mathrm{m}$ (range, 0.33 to $17.17 \mu \mathrm{m}$ ) from the constrained fit.

\section{Discussion}

The concentrations of chromium and cobalt in the joint 1 fluid of patients with a metal-on-metal device can reach

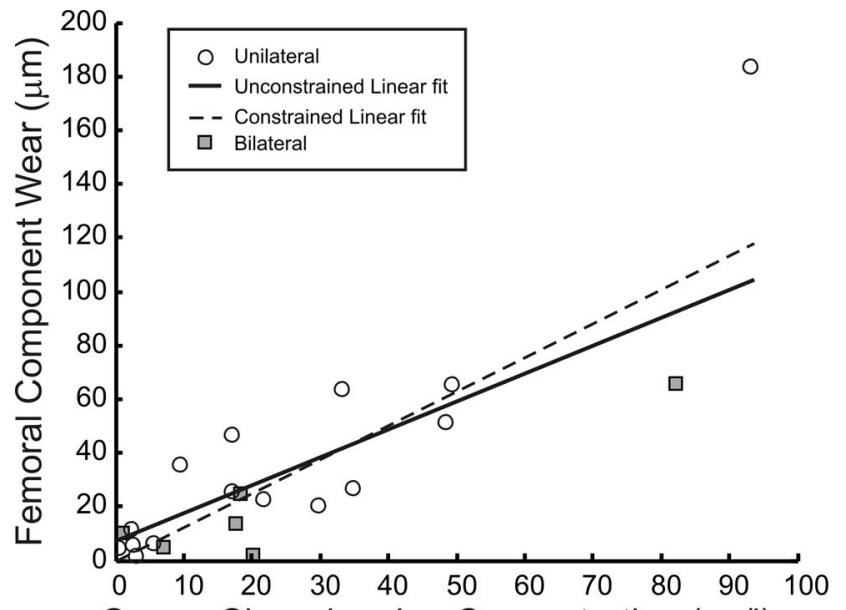

Fig. 4

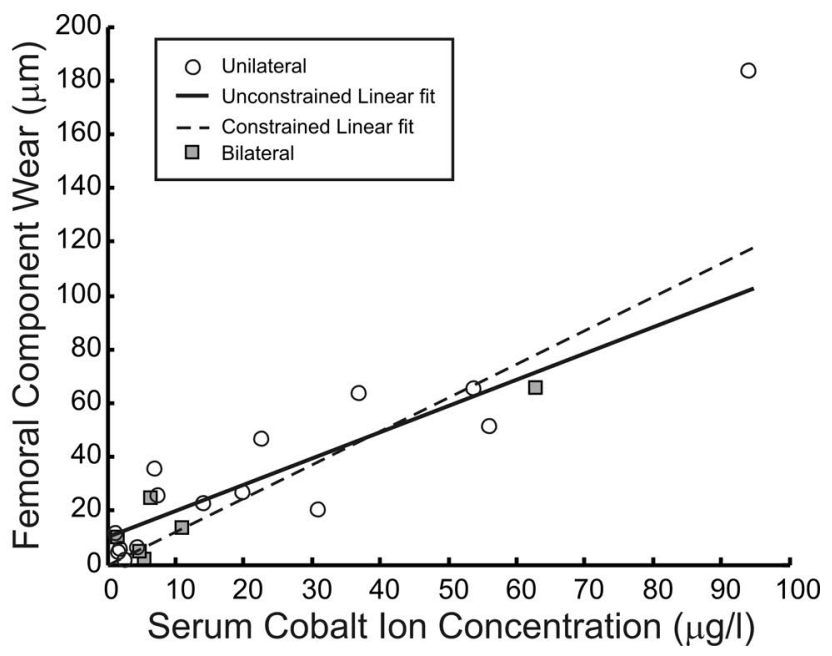

Unconstrained and constrained linear fits to the relationships between femoral component wear and serum metal-ion concentrations. Only data for the fifteen patients with a unilateral arthroplasty and for whom wear measurements were available were used to develop the regression lines. 
The Journal of BOnE \& JOINT SURGERY • JBIS.ORG VOLume 90-A · SuPPlement $4 \cdot 2008$
Metal Ion Measurement as a Diagnostic Tool to

Identify Problems with Metal-on-Metal Hip Resurfacing extremely high values, which are at least an order of magnitude higher than those measured in the serum. However, our data clearly show a strong correlation between measured serum and joint fluid concentrations of metal ions. Moreover, we found surprisingly strong and highly significant correlations between the maximum wear-scar depth and the metal ion concentrations in both serum and joint fluid. Higher serum and joint fluid metal-ion concentrations as well as higher wear were significantly associated with the finding of metallosis during revision. The lowest value of the interquartile range for the serum metal-ion concentrations in these patients (17 $\mu \mathrm{g} / \mathrm{L}$ for the chromium level and $19 \mu \mathrm{g} / \mathrm{L}$ for the cobalt level) represents the level above which metallosis is highly likely to be present. It should be noted that the average time that the implant was in situ was 2.9 years in our series of patients and that perhaps lower metal concentrations over a longer period in situ will also result in metallosis.

It was interesting that there was no significant difference in the median serum metal-ion level between the patients with a unilateral arthroplasty and those with a bilateral arthroplasty in our study. This finding is probably due to the fact that the much greater amount of ions originating from the poorly functioning implants in the bilateral cases dominated the overall serum measurement; however, the relatively small number of subjects in the study could also account for the finding.

We were able to construct both linear and exponential relationships between serum and hip-joint-fluid metal-ion concentrations. The relationship between serum and joint fluid chromium levels appeared to be exponential, but there were relatively few data points with high values for the joint fluid metal-ion levels. Even with use of robust methods, the exponential data fit was susceptible to outlier data points. However, the linear fit still provides a reasonable estimate, and probably this fit is less sensitive to the outlier values. In terms of predicting joint fluid concentrations from serum concentrations, the exponential relationship was better, but the error increased dramatically for high serum values. The relationship between serum and joint fluid cobalt concentrations was found to be less clearly exponential; the linear fit was better able to predict joint fluid concentrations from serum values. For the linear fits, the confidence intervals for the gradients were considerably smaller than those for the intercepts. The joint fluid level of chromium was found to be approximately fifty times the serum level, whereas the joint fluid level of cobalt was approximately forty times the serum level.

A surprising outcome was that both serum chromium and serum cobalt levels were strongly correlated with our measure of femoral component wear. A limitation of our study is that we could only reasonably quantify wear by measuring the maximum depth of the wear scar and we could not reliably measure volumetric wear. We would have expected a weaker relationship than the one that we found; it seems to be logical that volumetric wear would be more closely related to the metal ion concentration than would a linear measure of wear. However, we can speculate that wear is highly localized in metal-on-metal couples, strongly suggesting that edge-loading is the dominant wear-generation mechanism. This underlines the importance of proper positioning of all types of metal-on-metal hip replacement devices.

Another limitation of the study is that the joint fluid was obtained after the joint was exposed, making contamination of the joint fluid by blood highly probable. In retrospect, the joint fluid should have been collected by aspiration prior to opening the joint. We therefore expect that the actual relationships between serum and joint fluid metal-ion concentrations are stronger than the ones that we found.

The clinical message from this study is that metal-ion measurement is a valuable additional tool for diagnosis and patient follow-up. We advocate routine measurement of serum metal-ion levels during the care of patients with a metal-on-metal device. In this series of patients undergoing revision arthroplasty, there was not a single case in which a high serum metal-ion concentration was not associated with a high joint fluid metal-ion concentration and a high wear value. The implication is that when high serum metalion measurements are recorded there may be a problem with the implant and the patient should be closely monitored. We found a strong association between high serum and joint fluid levels of chromium and cobalt and a finding of metallosis at revision, an observation that supports the use of metal-ion measurements as a diagnostic screening test. Early revision of a metal-on-metal prosthesis in a patient with high serum metal-ion levels may help to avoid metallosis and its associated problems $s^{9,10,12,14}$. In our experience, patients in whom the joint tissues are severely affected by metallosis (for example, those with extensive synovitis, expanded bursae with large volumes of discolored fluid, and osseous changes such as femoral neck narrowing or osteolysis) require a more thorough débridement during revision surgery, which can result in a higher risk of postrevision complications such as dislocation ${ }^{15}$. Conversely, patients with well-positioned implants and low metal-ion levels are likely to be at a low risk for metallosis and can be monitored less frequently. If a patient with a bilateral replacement has high serum metal-ion values and no conclusive diagnosis can be made on the basis of the radiographic evaluation, performing a joint aspiration and measuring metal ion concentrations in the joint fluid may enable one to determine the side on which the implant is functioning poorly and that requires closer monitoring.

In conclusion, measurements of serum ion concentrations of chromium and cobalt can be used to estimate the amount of wear taking place in metal-on-metal hip-replacement devices. Serum metal-ion measurements are important for the clinical management of patients with metal-on-metal implants and should be routinely performed. Patients presenting with high serum metal-ion levels should be closely monitored, as early revision may be necessary. Finally, serum chromium-ion levels of $>17 \mu \mathrm{g} / \mathrm{L}$ and serum cobalt-ion levels of $>19 \mu \mathrm{g} / \mathrm{L}$ are more likely to be associated with metallosis. 
The Journal of Bone \& JoInt Surgery - JBJS.org VOLUME $90-\mathrm{A} \cdot$ SUPPLEMENT $4 \cdot 2008$
Metal Ion Measurement as a Diagnostic Tool to Identify Problems with Metal-on-Metal Hip Resurfacing
K. De Smet, MD

A. Calistri, MD

ANCA Medical Centre, Krijgslaan 181, 9000 Ghent, Belgium

R. De Haan, MD

University Hospital Brussels, Laarbeeklaan 101, 1090 Brussels, Belgium

P.A. Campbell, $\mathrm{PhD}$

E. Ebramzadeh, $\mathrm{PhD}$

J. Vernon Luck Sr., MD Orthopaedic Hospital Research Center,
2400 South Flower Street, Los Angeles, CA 90007

C. Pattyn, MD

University Clinic, Ghent University Hospital, De Pintelaan 185, 9000 Ghent, Belgium

H.S. Gill, DPhil

Botnar Research Centre, Nuffield Orthopaedic Centre, Oxford OX3 7LD, United Kingdom

\section{References}

1. National Joint Registry for England and Wales. 1st annual report. Hempstead, England: The National Joint Registry (NJR) Centre; 2004.

2. Amstutz HC, Grigoris P. Metal on metal bearings in hip arthroplasty. Clin Orthop Relat Res. 1996;329 Suppl:S11-34.

3. McMinn D, Treacy R, Lin K, Pynsent P. Metal on metal surface replacement of the hip. Experience of the McMinn prothesis. Clin Orthop Relat Res. 1996;329 Suppl:S89-98.

4. McMinn D, Daniel J. History and modern concepts in surface replacement Proc Inst Mech Eng [H]. 2006;220:239-51.

5. Anissian L, Stark A, Dahlstrand H, Granberg B, Good V, Bucht E. Cobalt ions influence proliferation and function of human osteoblast-like cells. Acta Orthop Scand. 2002;73:369-74.

6. Keegan GM, Learmonth ID, Case CP. Orthopaedic metals and their potential toxicity in the arthroplasty patient: a review of current knowledge and future strategies. J Bone Joint Surg Br. 2007;89:567-73.

7. Back DL, Young DA, Shimmin AJ. How do serum cobalt and chromium levels change after metal-on-metal hip resurfacing? Clin Orthop Relat Res. 2005;438:177-81.

8. Jacobs JJ, Skipor AK, Patterson LM, Hallab NJ, Paprosky WG, Black J, Galante JO. Metal release in patients who have had a primary total hip arthroplasty.
A prospective, controlled, longitudinal study. J Bone Joint Surg Am. 1998;80: 1447-58.

9. Park YS, Moon YW, Lim SJ, Yang JM, Ahn G, Choi YL. Early osteolysis following second-generation metal-on-metal hip replacement. J Bone Joint Surg Am. 2005;87:1515-21.

10. Boardman DR, Middleton FR, Kavanagh TG. A benign psoas mass following metal-on-metal resurfacing of the hip. J Bone Joint Surg Br. 2006;88:402-4.

11. Pandit $H$, Glyn-Jones $S$, McLardy-Smith P, Gundle R, Whitwell D, Gibbons CL, Ostlere S, Athanasou N, Gill HS, Murray DW. Pseudotumours associated with metal-on-metal hip resurfacings. J Bone Joint Surg Br. 2008;90:847-51.

12. Milosev I, Pisot V, Campbell $P$. Serum levels of cobalt and chromium in patients with Sikomet metal-metal total hip replacements. J Orthop Res. 2005;23:526-35.

13. MacDonald SJ, Brodner W, Jacobs JJ. A consensus paper on metal ions in metal-on-metal hip arthroplasties. J Arthroplasty. 2004;19(8 Suppl 3):12-6.

14. Milosev I, Trebse R, Kovac S, Cör A, Pisot V. Survivorship and retrieval analysis of Sikomet metal-on-metal total hip replacements at a mean of seven years. J Bone Joint Surg Am. 2006;88:1173-82.

15. De Haan R, Su EP, Campbell PA, De Smet K. Revision experience of metal-onmetal hip resurfacing arthroplasty. J Bone Joint Surg Br. 2008. In press. 